\title{
Diversity of African forest mollusc faunas: what we have learned since Solem (1984)
}

\author{
M. B. Seddon ${ }^{1}$, P. Tattersfield ${ }^{1}$, D. G. Herbert ${ }^{2}$, B. Rowson ${ }^{1}$, C. N. Lange ${ }^{3}$, C. Ngereza ${ }^{4}$, \\ C. M. Warui ${ }^{4}$ and J. A. Allen ${ }^{5}$ \\ ${ }^{1}$ National Museum of Wales, Department of Biodiversity and Systematic Biology, \\ Cathays Park, Cardiff CF1 3NP, UK \\ ${ }^{2}$ Natal Museum, P. Bag 9070, Pietermaritzburg 3200, South Africa and School of Botany \& Zoology, \\ University of KwaZulu-Natal, P. Bag X01, Scottsville, Pietermaritzburg, 3209, South Africa; \\ ${ }^{3}$ National Museum of Kenya, Department of Invertebrate Zoology, P.O. Box 40658, Nairobi, Kenya \\ ${ }^{4}$ National Museums of Tanzania, P.O. Box 512, Dar es Salaam, Tanzania \\ ${ }^{5}$ University of Southampton, Biodiversity and Ecology Division, \\ School of Biological Sciences Southampton S016 7PX, UK
}

\begin{abstract}
We report on studies in Tanzania, Kenya, Uganda and South Africa over the past 22 years that have yielded estimates of land-snail diversity in the main forest types occurring in East and eastern southern Africa. When supplemented with the results of similar research in Madagascar and West Africa by other workers, the information provides a more detailed picture of the patterns of land-snail diversity on the continent than was available to Solem (1984). We describe our field methods, re-examine Solem's (1984) assessments of sympatric, allopatric and mosaic diversity patterns in African forests and provide a review of overall species number at continental, regional and country-wide scales, and in the main African forest biomes that have been studied.
\end{abstract}

Key words: Mollusca, biodiversity, Africa, forests, hotspots, land-snails.

\section{INTRODUCTION}

In Africa, the Eastern Arc Region and the West African Guinea forests, together with the Madagascan forests, represent three of the 25 biodiversity hotspots in the world (Myers et al., 2000). Amongst global biodiversity hotspots, this reflects the fact that tropical mountain forests often hold larger numbers of plant species per area than lowland rainforests; they are much smaller, often highly fragmented, and frequently function as important hydrological catchments. Lowland rainforests are also rich, and the Congo Basin represents one of the last remaining wilderness areas (Mittermeier et al., 2003) where there are large numbers of endemic species, but where the level of threat is not as acute as in the hotspots.

Until recently, knowledge of the contribution of land molluscs to this forest diversity has been only fragmentary. The history of malacological exploration in Africa has been described in the numerous profiles of East African malacologists and collectors compiled by Bernard Verdcourt in the Newsletter of the Conchological Society of Great Britain and Ireland (Verdcourt, 1972). Overviews of African molluscan biogeography have been presented by Bourguignat (1889) and Germain
(1923, 1934, 1935), and the publication of nonmarine mollusc checklists for parts of Africa (Verdcourt, 1983; Bruggen and Meredith, 1984) has also assisted in work on the region. The monograph by von Martens (1889) was the first attempt at a comprehensive account of parts of the East African fauna. Notable later papers on the non-marine mollusc fauna including its ecology, diversity and biogeography are those of Connolly (1939), Bruggen and Meredith (1984), Bruggen (1969, 1970 and 1981) and Verdcourt (1972, 1984). Verdcourt's (1984) paper on geographical discontinuities in the fauna, and the value of different taxa for biogeographical interpretation followed on from his previous presentation to the Conchological Society of Great Britain and Ireland (Verdcourt, 1972). Bruggen (1986) provided an analysis of land snails in the Afrotropical Region at family and generic levels, much of which was based on previous papers (Bruggen, 1969, 1977, 1980, 1982).

In the Alan Solem Memorial Symposium at the Unitas Malacologica Congress in Siena (1992), Bruggen (1995) estimated that there might be about 6,000 species of non-marine mollusc in sub-Saharan Africa and this remains the most up to date estimate for the region. Terrestrial mollusc diversity 
is recognised to be high in eastern, central and southern Africa, with over 2,000 documented species and many other nominal taxa that remain to be described. In East Africa, about $83 \%$ of the land snail fauna is believed to be restricted to forest habitats (Verdcourt, 1972). Since forest habitat currently covers only about $2-3 \%$ of the land area in much of East Africa, and is under severe human pressure, this undoubtedly represents a conservation concern.

When presenting his world model of land snail diversity and abundance, Solem (1984) drew on observations made in Africa by Verdcourt and van Bruggen, and used this information along with similar data from elsewhere in the world to develop and support his ideas. Solem (1984) recognised that high levels of local species diversity can be reached in three principal ways: a) sympatric diversity reflecting the high numbers of species living in exactly the same place; b) allopatric diversity, where many species with short ranges replace each other geographically and c) mosaic diversity, where species are restricted to distinct plant communities or fine-scale habitats in a broader, more heterogeneous system.

He noted that land snails can exemplify each of these different types of diversity, which he distinguished and used information available from African sites to support his views on sympatric and allopatric diversity patterns, but did not report any examples of mosaic diversity patterns on the continent. Using the data provided by land snail specialists around the world, he then presented a series of generalisations about land-snail diversity and abundance in the world's principal vegetation types (Table 1).

In the 20 years since Solem's review, there has been a considerable advance in knowledge relating to the patterns of distribution, species diversity and species abundance for forest snails in Africa, and indeed elsewhere in the tropics. Since 1993, we have surveyed the land snail fauna in over 50 different forests in Kenya, Tanzania, Uganda and South Africa, and we use these data in this paper to reexamine some of Solem's (1984) conclusions. In particular, we contrast the levels of diversity and abundance and the composition of the land snail faunas in lowland and montane forest types in several African countries. We also refer to other research that has been undertaken recently elsewhere in Africa, especially in Cameroon (de Winter and Gittenberger, 1998) and Madagascar (Emberton, 1995a, b; Emberton et al., 1999).

\section{METHODS}

\section{Snail Sampling Methods}

The surveys and findings reported in this paper are restricted to forest sites. Early work in Kakamega Forest, western Kenya (Tattersfield, 1996) revealed several potential problems associated with mollusc survey in tropical forests. Firstly, the low or very low levels of mollusc abundance often encountered demonstrated that considerable sampling effort would be required to obtain reasonably comprehensive inventories. Secondly, that plot sizes would need to be quite large in order to detect the species that were sparsely distributed. In addition, it was noted that a significant proportion of the fauna at some sites comprised cryptic, litter-dwelling micro-species, which could only be detected by litter sieving methods. These considerations led to the development of a standard methodology which addressed the main sampling problems by combining a period of fixed-time direct searching with the collection and subsequent sieving and sorting of standardised volumes of forest floor leaf litter.

Practical considerations have inevitably influenced the intensity of sampling possible at some sites, but in general, our 'standard sampling plot' has involved a combination of direct searching for a total of 4 person hours (generally by 2 people for 2 hours each), supplemented by the sieving of about 41 . of leaf litter. In South Africa, we applied a similar but stricter sampling protocol, based on a measured $20 \times 20 \mathrm{~m}$ plot, 2 hours of sampling and a more precisely measured volume of litter. However, these differences in methodology are relatively minor and are unlikely to materially influence the broader scale patterns examined in this paper. All molluscs obtained using these two methods were collected and subsequently identified or assigned to morphospecies. Specimens were

Table 1 Summary of Solem's (1984) review of land snail habitability of the major world vegetation types

\begin{tabular}{ll}
\hline Habitat & Molluscan communities \\
\hline Rainforest & Generally neither diverse nor abundant except on ecotonal fringes \\
Monsoon Forest & Often relatively diverse and abundant \\
Deciduous Temperate Forest & Moderately abundant, but diverse only in geological refugia \\
Evergreen Forest & Generally low diversity and abundance (but some exceptions in mature coniferous forest) \\
Grassland & Diversity low but abundance maybe high where rainfall is adequate \\
Desert & Classical flat, open desert lands are 'basically snail-free' \\
\hline
\end{tabular}


classified as live or dead although the analyses are based on all the specimens, i.e. live plus dead, and those derived from both sampling methods.

Replicate standard plots have been sampled in most of the forest sites, often with the assistance of trained local people. Species accumulation curves, drawn up in relation to both the duration of sampling and the number of plots, were investigated during early stages of the project and these indicated that between 12 and 33 hours of sampling would be required to detect about $90 \%$ of the fauna (Tattersfield, 1997). This level of sampling has not been possible at many of the sites, and therefore some species have undoubtedly been missed, especially at the level of single plots; forest inventories are unlikely to be complete. Tattersfield et al. (1998 and 2001a,c) provide further details on the sampling methods.

\section{Forest, Site and Plot Selection}

Advice from local foresters was used to select the least disturbed forest sites in a given area, with due consideration to ease of access. Figure 1 shows the distribution of the forests, and the phytogeographical zones (following White, 1983) in which they occur. White's (1983) zones reflect the major variation in vegetation across the continent. Although floristically based they are clearly related to factors such as rainfall, elevation, latitude and proximity to the sea. Zones covered in the surveys included lowland Guineo-Congolian rainforest (sampling sites from the eastern fringe of the Congo Basin), coastal forests in the Zanzibar-Inhambane and Tongaland-Pondoland regions extending along the Indian Ocean coastline from central Kenya to Durban, South Africa, and Afromontane forests at numerous locations extending from the isolated
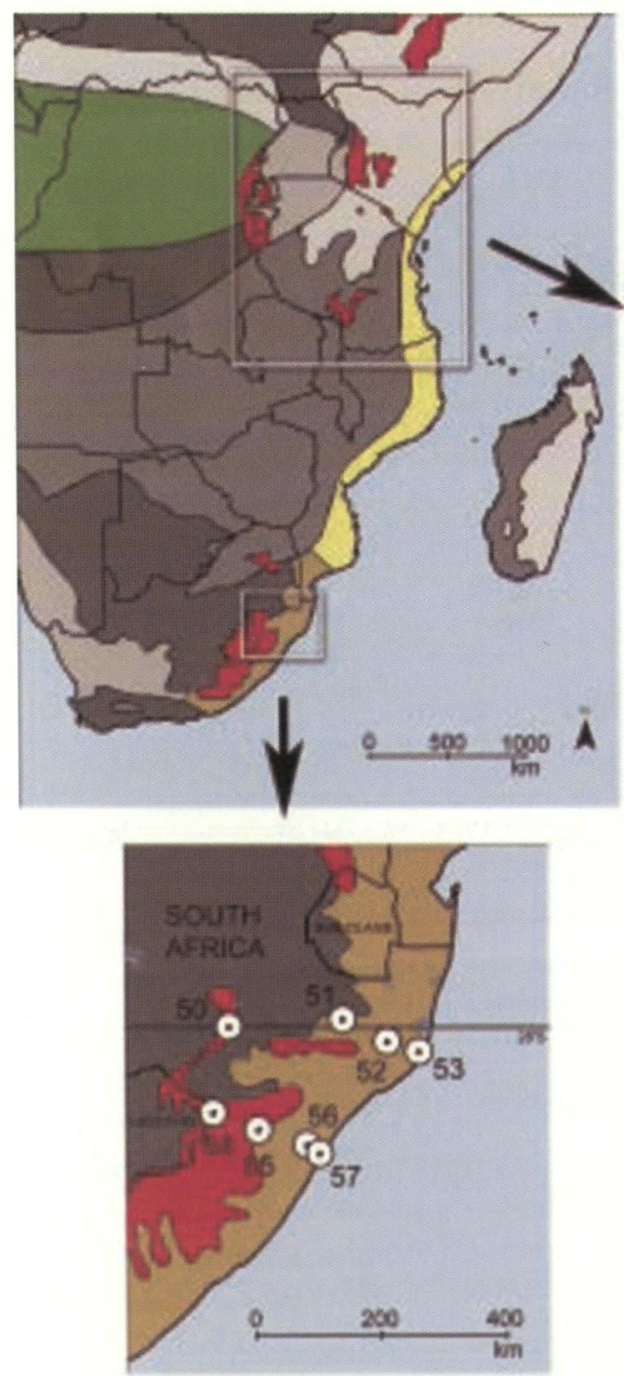

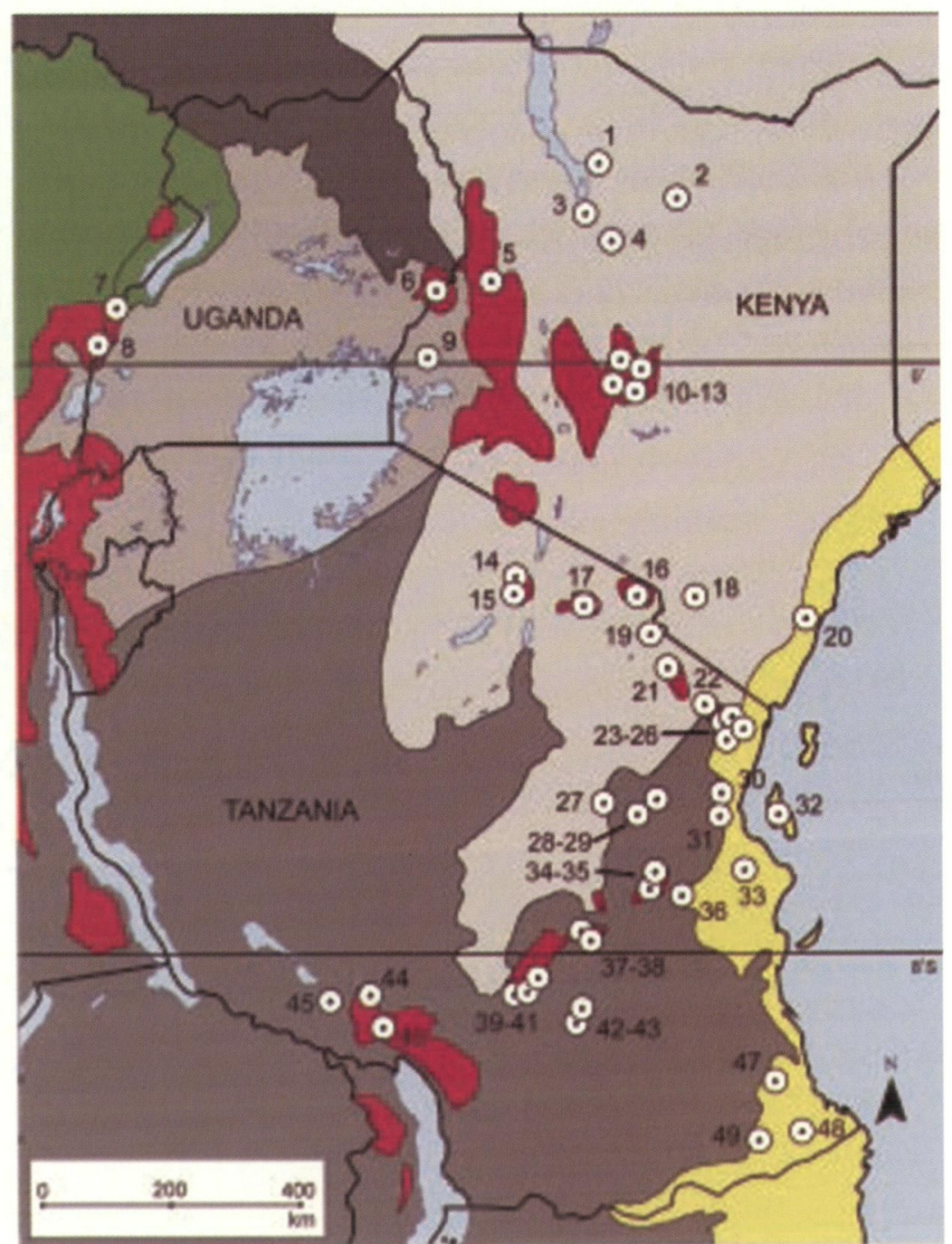

Tonga-Pondoland regional mosaic

\section{Zanzibar-Inhambane regional mosaic}

Other vegetation zones of White (1983)

Figure 1 Location of study sites and associated phytogeographic zones. 
mountains in northern Kenya (Kulal, Marsabit, etc.) to the Rungwe and Mporoto massifs that lie north of Lake Nyasa in southern Tanzania and the Drakensberg Range in KwaZulu-Natal. Forests at intermediate elevations, lying between lowland or coastal and montane habitats were also sampled and are discussed separately. These transitional forests include, for example, Kakamega Forest in western Kenya, and sites at intermediate elevations on the slopes of the Eastern Arc ranges mainly in Tanzania (e.g. Usambara, Uluguru, Udzungwa).

At each site a series of plots was chosen, with the plots being situated away from clearings or forest edges. The groups of plots were also stratified at many sites, to provide coverage of major gradients or local variation, for example in terms of elevation, topography, aspect or vegetation type. Plot size was not fixed (except in South Africa), but usually did not exceed $30 \mathrm{~m} \times 30 \mathrm{~m}$, although occasionally some plots may have covered up to about a hectare. Forest height and percentage canopy cover, local topography, aspect, and the presence and relative frequency of molluscan microhabitats were recorded on each plot. At many sites the $\mathrm{pH}$ of the residue of each litter sample was measured in aqueous solution $\left(10 \mathrm{~cm}^{3}\right.$ water plus $5 \mathrm{~cm}^{3}$ soil) and other soil chemistry parameters were also measured on Mt Kenya, in north Kenya and in South Africa.

Material from the surveys is deposited at National Museum of Wales, National Museums of Kenya,
National Museums of Tanzania and Natal Museum, Pietermaritzburg. The location of material and further detailed results can be found in papers dealing with specific sites and areas (Tattersfield, 1996, 1998; Tattersfield et al., 1998, 2001a, and in review).

\section{RESULTS AND DISCUSSION}

The data obtained during the project enable the levels of forest mollusc diversity and abundance to be reviewed at various geographical scales across East Africa and in KwaZulu-Natal, South Africa. The smallest sampling unit, the standard plot (typically $<1$ ha), provides information on sympatric diversity whereas comparisons between plots, sampling sites, forests and mountain ranges enable allopatric effects to be studied or mosaic diversity patterns to be related to elevational gradients or other environmental variation. Larger scale geographical variation can be studied by comparing the faunas from the major African forest types defined by White (1983). De Winter and Gittenberger (1998) and Emberton et al. (1999) provide additional diversity data from Cameroon and Madagascar respectively.

\section{Sympatric species diversity}

Solem (1984) used comments by Bernard Verdcourt and A. C. van Bruggen, based on their

\section{Mollusc site diversity (mean species/plot) in geographical zones}

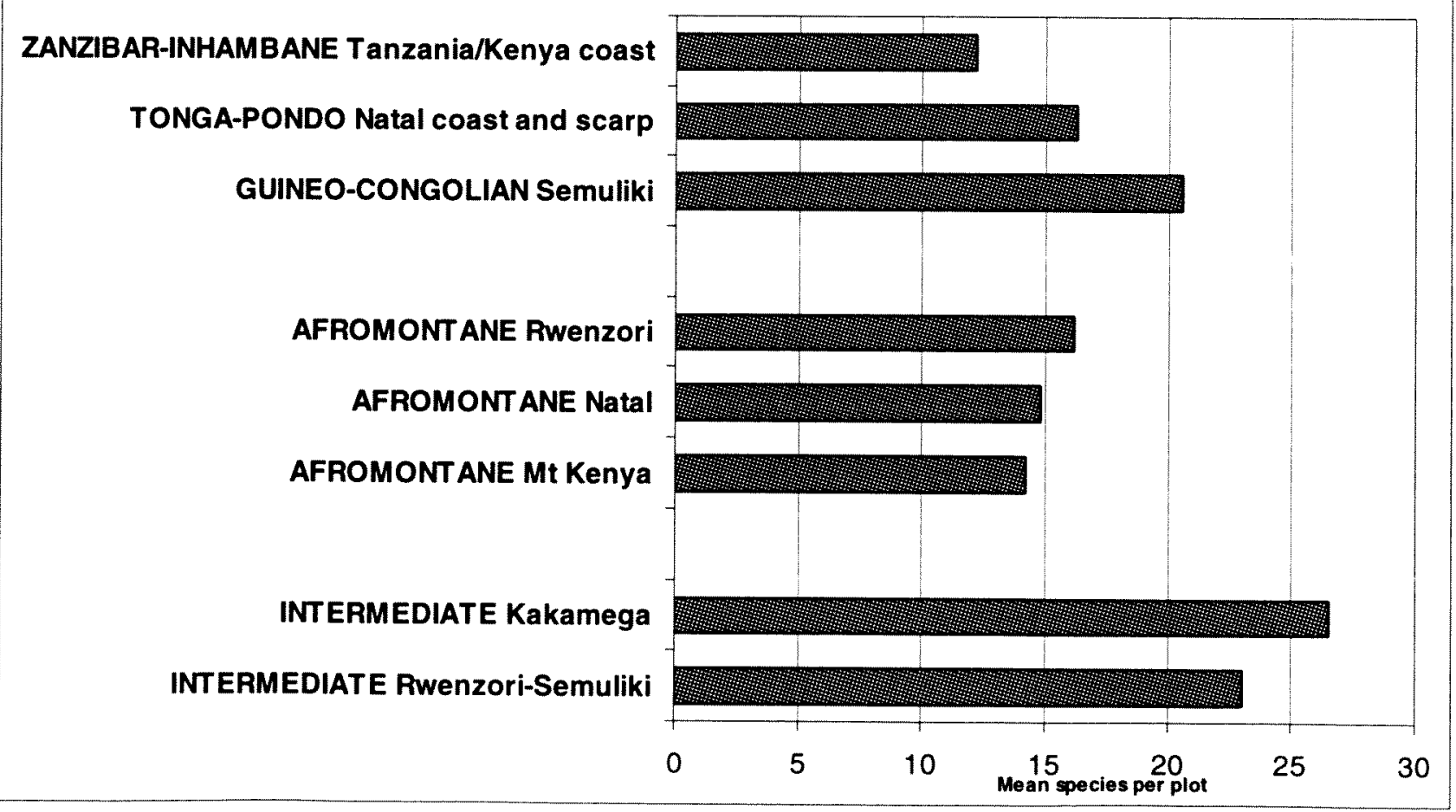

Figure 2 Sympatric mollusc diversity in African forests in major vegetation zones, as estimated by mean number of species per plot. 
Table 2 Land-snail diversity and abundance estimates from forest sites in Africa

\begin{tabular}{|c|c|c|c|c|c|c|c|c|c|}
\hline Site & Forest Type & Altitude & $\begin{array}{l}\text { No } \\
\text { plots }\end{array}$ & $\begin{array}{l}\text { Total } \\
\text { hours }\end{array}$ & $\begin{array}{l}\text { Range of } \\
\text { species } \\
\text { number }\end{array}$ & $\begin{array}{l}\text { Mean } \\
\text { species } \\
\text { per plot }\end{array}$ & $\begin{array}{c}\text { Mean } \\
\text { specimens } \\
\text { per hour }\end{array}$ & $\begin{array}{l}\text { Total } \\
\text { species }\end{array}$ & Notes \\
\hline Arabuko-Sokoke, Kenya & Coastal, Zanzibar-Inhambane & $<100$ & 30 & 30 & $5-13$ & $6.3-8.0$ & 42.1 & 25 & Lange and Mwinzi, 2003 \\
\hline $\begin{array}{l}\text { Cape Vidal, Kwazulu Natal, } \\
\text { S. Africa }\end{array}$ & Coastal, Tonga-Pondoland & $<100$ & 8 & 16 & $20-25$ & 21.75 & 132.0 & 35 & $\begin{array}{l}\text { Herbert, Tattersfield and } \\
\text { Seddon, in prep }\end{array}$ \\
\hline $\begin{array}{l}\text { Hawaan, Kwazulu Natal, } \\
\text { S. Africa }\end{array}$ & Coastal, Tonga-Pondoland & $<100$ & 8 & 16 & $14-20$ & 17.38 & 119.9 & 29 & $\begin{array}{l}\text { Herbert, Tattersfield and } \\
\text { Seddon, in prep }\end{array}$ \\
\hline $\begin{array}{l}\text { Injasuthi, Drakensberg Mts, } \\
\text { S. Africa }\end{array}$ & Afromontane & $1,600-1,700$ & 8 & 16 & $15-20$ & 18.125 & 200.1 & 27 & $\begin{array}{l}\text { Herbert, Tattersfield and } \\
\text { Seddon, in prep }\end{array}$ \\
\hline $\begin{array}{l}\text { Normandien, Drakensberg Mts, } \\
\text { S. Africa }\end{array}$ & Afromontane & $1,600-1,950$ & 8 & 16 & $7-13$ & 10 & 38.9 & 22 & $\begin{array}{l}\text { Herbert, Tattersfield and } \\
\text { Seddon, in prep }\end{array}$ \\
\hline Kakamega, Kenya & Transitional, Lowland-Afromontane & 1,600 & 8 & 16 & $23-30$ & 26.5 & 149.1 & 41 & Tattersfield et al, 2001 \\
\hline Kakamega, Kenya & Transitional, Lowland-Afromontane & 1,600 & 27 & & $13-33$ & 23.4 & & 51 & Tattersfield, 1996 \\
\hline $\begin{array}{l}\text { Kimboza, Uluguru Mts, } \\
\text { Tanzania }\end{array}$ & Coastal, Zanzibar-Inhambane & 350 & 12 & 34.75 & $9-25$ & 18.75 & 26.9 & 45 & Tattersfield et al, 1998 \\
\hline Mazumbai, W Usambara & Transitional, Coastal-Montane & $1,620-1,730$ & 8 & 29.17 & $12-22$ & 16.88 & 25.7 & 36 & Tattersfield et al, 1998 \\
\hline $\begin{array}{l}\text { Mbomole, E. Usambara, } \\
\text { Tanzania }\end{array}$ & Transitional, Coastal-Montane & 1,000 & 7 & 33.83 & $13-33$ & 24.43 & 30.7 & 57 & Tattersfield et al, 1998 \\
\hline $\begin{array}{l}\text { Ngarama and Pindiro, } \\
\text { Tanzania }\end{array}$ & Coastal, Zanzibar-Inhambane & $350-500$ & 7 & 19.5 & 9-14 & $11.25-12.33$ & $18.08-29.07$ & 29 & Tattersfield, 1996a, 1998 \\
\hline $\begin{array}{l}\text { Nguru South, Nguru Mts, } \\
\text { Tanzania }\end{array}$ & Transitional, Coastal-Montane & 1,040 & 4 & 22.25 & $4-8$ & 5.5 & 2.2 & 13 & Tattersfield et al, 1998 \\
\hline $\begin{array}{l}\text { Rwenzori, western slopes, } \\
\text { Uganda }\end{array}$ & Afromontane & 2,000 & 6 & 21 & $19-30$ & 23 & 50.6 & 45 & $\begin{array}{l}\text { Tattersfield and Allen, } \\
\text { unpublished }\end{array}$ \\
\hline $\begin{array}{l}\text { Rwenzori, western slopes, } \\
\text { Uganda }\end{array}$ & Afromontane & 2,500 & 6 & 24 & $11-27$ & 14 & 10.3 & 39 & $\begin{array}{l}\text { Tattersfield and Allen, } \\
\text { unpublished }\end{array}$ \\
\hline Semuliki, Uganda & Guineo-Congolian & $740-790$ & 13 & 48 & $15-31$ & 21 & 27.8 & 61 & $\begin{array}{l}\text { Tattersfield and Allen, } \\
\text { unpublished }\end{array}$ \\
\hline $\begin{array}{l}\text { Uluguru North, Tanzania } \\
\text { near Lolodorf, Cameroon }\end{array}$ & $\begin{array}{l}\text { Transitional, Coastal-Montane } \\
\text { Guineo-Congolian }\end{array}$ & $\begin{array}{l}1,250-1,500 \\
420-480\end{array}$ & $\begin{array}{l}13 \\
16\end{array}$ & $\begin{array}{c}45.67 \\
16\end{array}$ & $\begin{array}{c}9-20 \\
20-45\end{array}$ & $\begin{array}{l}13.38 \\
29.5\end{array}$ & $\begin{array}{l}17.2 \\
51.9\end{array}$ & $\begin{array}{l}34 \\
76\end{array}$ & $\begin{array}{l}\text { Tattersfield et al, } 1998 \\
\text { de Winter and Gittenberger, } \\
1998 \text {. Used } 20 \mathrm{~m} \times 20 \mathrm{~m} \text { plots } \\
\text { for } 2 \text { person-hours. Also } \\
\text { beat vegetation and had a } \\
\text { 'bonus' } 81 \text { litter. } 1995 \\
\text { data only }\end{array}$ \\
\hline
\end{tabular}


extensive field experience, when discussing sympatric mollusc diversity in Africa. Verdcourt reported that East African 'wet forests' might yield up to 20-25 species from a small area, although 1015 species was more typical, whereas in South Africa, van Bruggen suggested that coexisting species numbers were lower, ranging from a typical 3 species per site to an exceptional 5-9 species. However, it is not clear whether van Bruggen's assessment included habitats other than forests, such as savanna, grassland and karoo, which tend to have lower diversity levels. Recently, Herbert and Kilburn (2004) stated that sympatric diversity in KwaZulu-Natal forests can reach 30 species. More generally, from world-wide sites, Solem concluded that only a few areas have more than 30 species occurring microsympatrically, with New Zealand providing the highest recorded microsympatric distributions with up to 70 species occurring at some sites (Solem et al., 1981). He thought that lowland rainforests were generally species-poor (Table 1).

The number of species and the number of specimens relative to sampling effort recorded in the standard plots provide estimates of sympatric diversity and relative snail abundance. Figure 2 shows the mean plot diversity from the sampled forests in different biogeographic zones. The highest mean diversities in our studies were 26.5 and 23 species per plot from Kakamega (western Kenya) and from a single plot at $1,300 \mathrm{~m}$ in western Uganda respectively, both of which are transitional forests. Lowland Guineo-Congolian rainforest is also relatively diverse with a mean of 20.6 species per plot, but the lowland coastal forests (both Zanzibar-Inhambane and Tonga-Pondoland), and Afromontane forests contain fewer sympatric species, with averages typically ranging from 13 to 16 species per plot. Elsewhere in Africa, higher diversities have been reported, such as in lowland Guineo-Congolian forest in Cameroon where de Winter and Gittenberger (1998) reported a mean of 29.5 species per $20 \times 20 \mathrm{~m}$ plot.

The mean plot diversity values given in Figure 2 obscure considerable variation in sympatric diversity levels; these may reflect varying amounts of sampling error. Table 2 shows the range in the number of species returned from replicate plots in a range of African forests. All the sites were relatively intensively sampled, with over 15 person hours being spent at several plots on each site. Plot returns are likely to be influenced by individual collector efficiency, and therefore our analysis focuses on the maximum numbers of species found. The influence of allopatric and mosaic diversity has been minimized by selecting groups of plots that do not encompass major elevational or other environmental variation. The total number of species recorded from the combined plots at a given site also provides a measure of sympatric diversity at a slightly larger geographic scale, although it may also incorporate mosaic effects resulting from small-scale, within-site habitat heterogeneity. The data include representative sites from the main biogeographical zones sampled, plus sites at transitional locations.

The transitional forest at Mbomole (East Usambara) returned the highest number of species (33) from a single plot in our studies, although this figure is exceeded in de Winter and Gittenberger's (1998) study in Cameroon. High single-plot diversity was also recorded in lowland rainforest at Semuliki (31 species), in transitional forest at Kakamega (30 species) and in Afromontane forest at 2,000 $\mathrm{m}$ in the Rwenzori Mountains, Uganda (30 species). Mean plot diversities were likewise high on these sites, ranging through 24.4 (Mbomole), 23.4 (Kakamega), 23.0 (Rwenzori), and 21.0 (Semuliki), thus indicating that the maximum single-plot figures were not exceptional. Some sites are characterised by low plot diversity, such as the transitional forest at Nguru South where the maximum plot richness was 8 species. There is considerable variation amongst the coastal forest localities and the two sites with the highest singleplot diversity, Cape Vidal and Kimboza, each with 25 species, both have base-rich soils. Cape Vidal is a dune system with calcium-rich soils $(\mathrm{pH} 7.5)$, and Kimboza is on metamorphozed limestone. At another less intensively sampled degraded forest site on a limestone site at Amboni near Tanga, Tanzania, 4 plots returned species counts of between 12 and 17 species (mean of 14.25) per plot (Tattersfield, 1998), and the site total was 50 species (Emberton et al., 1997). However, in general most coastal forest sites have mean plot diversity levels in the range of 6-12 species per plot (Tattersfield, 1998).

The mean number of specimens returned per person-hour (Table 2) provides a simple estimate of relative snail abundance. The estimates are based on standard plots, and include live and dead material derived from both the direct searching and litter sieving methods. These values span a very wide range, from 2.2 at the low diversity site at Nguru South to over 200 in the Afromontane forest at Injasuthi. It is clear that molluscs are very abundant at some sites but sparse at others, but the data need to be interpreted with caution. At Cape Vidal for example, the large number of specimens reflects, in part, the high abundance of relatively large dead shells, which persist longer in the site's base-rich soils. In contrast, the high abundance at Injusuthi is a result of the large numbers of a few small, litter-dwelling species, which were obtained by sieving. Abundance was much lower at Normandien, the other Afromontane forest site in the Drakensberg Mountains. Emberton et al. (1997) provide estimates of relative snail density from 
Tanzanian forests sites ranging from 4.5 to 88.5 snails per person-hour of collecting time.

\section{Allopatric Diversity and Mosaic Diversity}

The increase in species number associated with an increase in the area of habitat has been termed beta diversity by Whittaker (1970). Although Solem (1984) did not refer to beta diversity directly, he did recognize two separate components of regional diversity, allopatric and mosaic diversity, which can contribute to high beta diversity in land snails. Allopatric diversity is the product of local speciation events that result in non-overlapping ranges. In contrast, mosaic diversity results from high habitat diversity and local environmental variation, where different species are associated with, for example, particular vegetation types, successional stages, microclimates or geological features.

Mainly based on his own published studies on Pacific Islands and Western Australian mountains, Solem (1984) commented that 'evidence was accumulating that allopatric diversity is exceptionally high among land snails'. He cited Verdcourt's report of altitudinal faunal stratification on Mt Kenya, and the high ratio of regional to local species number in the Usambara Mountains, Tanzania, as evidence for local speciation effects and allopatric diversity, but he did not make reference to any African examples when discussing mosaic diversity. We have found similar high ratios of regional to local species number on other Eastern Arc ranges, including the Ulugurus (unpublished).

Our studies have revealed varying levels of diversity and faunal variation within African forests, and it is clear that both allopatric and mosaic elements contribute significantly to regional diversity levels, at least within some of the major biogeographical zones. Within sites, the richest fauna detected in our studies so far was in Mwanihana Forest Reserve with 64 species (Tattersfield et al., in review), where forest extends continuously between about 400-2,000 m elevation on the eastern escarpment of the Udzungwa Mountains, Tanzania; elevational variation in composition is clearly a major contributor to diversity at this site. We have been able to distinguish specialist montane and lowland groups of species (Tattersfield et al., in review), with a faunal discontinuity at about $1,000 \mathrm{~m}$ elevation. Such variation would appear to be mainly driven by environmental factors, and would thus represent examples of Solem's (1984) mosaic diversity. Similarly, we have recorded major faunal change along elevational gradients on Mount Kenya (Tattersfield et al, 2001a; Warui et al., 2001) where much of the faunal variation can be attributed to the levels of rainfall and associated environmental variables. Other species-rich forest sites in East
Africa include Kakamega Forest, Kenya with 58 species (Tattersfield et al., 2001; Tattersfield, 1996) and Mbomole Forest, East Usambara, Tanzania with 57 species (Tattersfield et al., 1998). Kakamega Forest spans a relatively small elevational range, and has a relatively homogenous fauna with little local variation (Tattersfield, 1996; Tattersfield et al., 2001c) apart from minor changes associated with features such as rivers and clearings. De Winter and Gittenberger (1998) reported a total of 76 species (1995 data) from an area of only $1 \mathrm{~km}^{2}$ of lowland rainforest in Cameroon. They found major betweenplot variation within this area, representing finescale habitat heterogeneity and mosaic effects without habitat correlation, the latter possibly a consequence of sampling error. As they say, the overall assemblage must be regarded as sympatric.

Having thus minimised the influence of allopatric replacement in the analysis of sympatric, i.e. site, diversity, we can now consider further the East African fauna in the light of Solem's comments on allopatry and "mosaic" diversity. However, it is often not possible to determine whether local speciation, mediated by history, or direct environmental factors are responsible for high levels of beta diversity at scales larger than our sites. In Tanzania and Kenya, both the Eastern Arc Mountains and Coastal Forests have been identified as centres of relict endemism for many groups of animals and plants with small species range sizes (Burgess and Clarke, 2000), and the situation for terrestrial molluscs is evidently similar. Tattersfield et al. (1998) provided a breakdown of the pre-1995 state of knowledge of the Eastern Arc malacofauna, showing that each mountain block harboured a number of endemics. Although there are still major taxonomic impediments, it would appear clear that closely related taxa occur on different mountain ranges of the Eastern Arc. Tattersfield (1998) reported many narrow-range endemics and high between-site turnover in the molluscs of the Tanzanian coastal forests. Emberton (1995a, b) and Herbert and Kilburn (2004) also report considerable allopatric diversity in the faunas of Madagascar and eastern South Africa respectively. Madagascar also appears to support high levels of sympatric diversity (Emberton et al., 1999).

Unfortunately, understanding the relative contribution of allopatric and mosaic effects to these patterns, and to overall regional diversity requires a deeper understanding of taxonomy and systematics than is currently available. We are working towards illustrated checklists and taxonomic descriptions (Seddon et al., in prep.) to help remedy the situation, but further systematic work on phylogenies is also needed. In the meantime, levels of between-site turnover and the spatial scales at which taxa are endemic are difficult to assess, and centres of allopatric and mosaic diversity can only 
be identified qualitatively. Solem (1984) implicitly acknowledged that cases of sympatric, allopatric and mosaic diversity were difficult to separate and depended on the scale of study. Finally, comparatively little is known about the effects of disturbance on the diversity of snails in East Africa. Tattersfield et al. (2001c), Tattersfield (1996) and Lange (2003) showed that species richness and evenness declined in plantation relative to mixed forest.

\section{Continental, Regional and Country-wide Species Diversity}

van Bruggen (1995) reviewed available evidence and concluded that there might be about 6,000 species of terrestrial molluscs in sub-Saharan Africa. However, there is currently no unified list of species for the subcontinent, and hence we must rely on regional and country lists (e.g. Verdcourt, 1983; van Bruggen, 1980; van Bruggen and Meredith, 1984) and the major monographs produced in the first half of the $20^{\text {th }}$ century (Connolly, 1939; Pilsbry, 1919). Although all the available lists are incomplete, some are clearly less comprehensive than others and many new taxa await description. Our work in East Africa has indicated that a significant proportion of the Tanzanian fauna requires formal description, whereas fewer undescribed taxa are present in Kenya, and possibly also in Uganda. De Winter and Gittenberger (1998) reported that there are many undescribed species in West Africa.

There have been several preliminary species checklists complied at a country level. More than 1,063 species of terrestrial molluscs (excluding subspecies and varieties) are known from East Africa (data from Verdcourt, 1983, Verdcourt, unpublished and Tattersfield, unpublished), with Kenya, Tanzania and Uganda supporting 514, 417 and 297 species respectively. Verdcourt (1983) lists 46 species from the islands of Zanzibar and Pemba, although Rowson (in prep.) lists 69 from these two Indian Ocean islands, plus nearby Mafia Island. Bernard Verdcourt has noted that the name Zanzibar used to be used as a generic place name for part of the East Africa coast as well as the island itself, and such problems with place names may lead to difficulties when assigning species to regions, especially where they are only known from "type locality" with poor localization. Connolly (1939) included 764 species of non-marine molluscs including freshwater species from southern Africa in his monumental monograph on the area south of the Zambezi and Cunene Rivers; a further 40 species were added to the south African list by van Bruggen (1970), and new taxa continue to be described (eg. Herbert, 2002, Bursey and Herbert, 2004). Herbert and Kilburn (2004) provide a detailed treatment of the fauna of eastern South
Africa, and comment that over 650 species of terrestrial mollusc are known from southern Africa as a whole. Van Bruggen (1980) compiled a preliminary checklist of Madagascan terrestrial molluscs, although many additional taxa have since been described (e.g. Emberton, 1994) and Emberton (1995b) assessed total species richness to be between 3 and 10 times the 378 species known at that time. Since then, Pearce (2003) has produced another list for Madagascar that includes 685 species. The Malawi fauna comprises at least 119 species (van Bruggen and Meredith, 1984; van Bruggen, 1993) although, again, additional taxa continue to be described from the country. The largest gap in our knowledge about regional and country faunas in sub-Saharan Africa is from West Africa and central Africa.

\section{Diversity in Major Phytogeographical Zones}

It is similarly not possible at present to compile comprehensive lists of terrestrial molluscs for White's (1983) vegetation zones, and opportunities for detailed analysis are based mainly on the restricted sampling that has been done in each area, further complicated by the taxonomic problems. However, preliminary checklists have been produced for the Eastern Arc chain of mountains (Tattersfield et al., 1998), coastal forests (Verdcourt in Burgess and Clarke, 2000), and Mount Kenya (Warui et al., 2001). Overall species richness may be broadly similar in some floristic zones; for example, 62 species were recorded during the limited survey in Semuliki in the Guineo-Congolian rainforests in west Uganda, whereas 79 species were found in dry coastal and escarpment forests in the TongalandPondoland zone in KwaZulu-Natal. However, other zones support many more species, especially where allopatric speciation effects contribute strongly to regional diversity levels, such as in the Eastern Arc chain of massifs in south-east Kenya and Tanzania. Similarly, Verdcourt (in Burgess and Clarke, 2000) lists 146 terrestrial species from the East African coastal forests, which extend from Somalia to Mozambique, where allopatric effects may also be strong (Tattersfield, 1998). Total species richness was also similar in the forests in each of the Afromontane massifs, although the number in the combined afromontane 'archipelago' is likely to be higher, but this cannot be estimated at present.

There is some evidence of faunal mixing in the transitional forests that lie between lowland and montane types. In Tanzania, for example, there appears to be an increase in sympatric diversity at intermediate elevations between coastal and Afromontane forest types in the Eastern Arc mountains. The presence of both rainforest and Afromontane species in plots at Kakamega Forest, western Kenya also accounts for the high diversity levels recorded there. However, overall, the 
different phytogeographic zones share rather few species, even where they occur in close geographical proximity. For example, Tattersfield and Allen (unpublished) found that Afromontane and lowland rain forest habitats in west Uganda shared only 22 of the total 117 species, despite being geographically close to each other (separated by a few 10s of kilometres) and, apparently, formerly contiguous. Tattersfield et al. (2001a, b) have discussed the Palaearctic element in the Afromontane fauna that is present in eastern Africa, and extends to Afromontane forests in southern Africa (Herbert et al., in preparation). Relatively few species appear to be truly widespread across several of the vegetation zones and these are mainly small species such as Kaliella barrakporensis, which was originally described from India. Some species, however, have large geographical ranges, such as Gulella handeiensis that occurs in Kakamega Forest west Kenya and in the East Usambara in east Tanzania (Verdcourt, 1983).

\section{CONCLUSION}

Much new information is now available about Africa's land-snail fauna and the levels and patterns of diversity that occur across the continent. Some of this information tends to confirm and extend Solem's (1984) preliminary speculations, such as the levels of sympatric diversity that have been recorded. It is clear that he underestimated sympatric richness in tropical forests, and, as might have been expected, the situation is evidently more complex than he originally presented, with strongly contrasting patterns in areas with different geological and environmental histories. Strong allopatric and local speciation effects are clearly important contributors to regional diversity levels in some areas, especially where there has been long uninterrupted forest cover (such as the Eastern Arc ranges), and these factors have led to some areas being identified as centres of endemism or 'hotspots of biodiversity'. Mosaic effects are also clearly important and reflect the strong ecological variation and gradients in many of the continent's regions, with distinct lowland and highland species sets being discernible along some extended elevational gradients.

Further geographical coverage outside eastern and southern Africa, and especially in the west and centre of the continent, is needed to develop a wider understanding of the patterns of molluscan diversity in sub-Saharan Africa. However, the main obstacle for more detailed and comprehensive analysis is the absence of a sound taxonomy. Recent new initiatives by Dai Herbert and Ben Rowson on phylogenies of several taxonomic groups will hopefully start addressing this deficiency, and should enable more robust ecological analysis in the future.

\section{ACKNOWLEDGEMENTS}

The Tanzania Commission for Science and Technology (COSTECH), Tanzania National Parks Authority (TANAPA) Department of Forestry and the Department of Catchment Forests granted permission to conduct research in Tanzania. The Office of the President, Department of Forestry and Kenya Wildlife Service gave permission to work in the forests of Kenya. Ezemvelo KZN Wildlife gave permission to work in KwaZulu-Natal.

The projects have been funded by grants from DEFRA Darwin Initiative (MBS, PT), National Museums of Wales (MBS, BR), Operation Raleigh (PT, JAA), NRF South Africa (DH, MBS, PT), British Ecological Society (PT), the Percy Sladen Fund (Linnean Society) (PT), WWF (CL) and FFI (CL).

We are grateful for the assistance provided during field work by many dedicated forestry officers, villagers from local communities, staff and students from local universities, wildlife clubs and museums.

\section{REFERENCES}

Bourguignat, J.R. (1889). Mollusques de l'Afrique équatoriale de Moguedouchou à Bagamoyo et de Bagamoyo au Tanganika. Paris, France.

Bruggen, A.C. van. (1969). Studies on the land molluscs of Zululand with notes on the distribution of land molluscs in southern Africa. Zoologische Verhandelingen, Leiden 103: 1-116.

Bruggen, A.C. van. (1970). Non-marine Mollusca. South African Animal Life, Stockholm, 14: 444-476.

Bruggen, A.C. van. (1977). A preliminary analysis of African non-marine Gastropoda Euthyneura families. Malacologia 16: 75-80.

Bruggen, A.C. van. (1980). A preliminary checklist of the terrestrial molluscs of Madagascar. Achatina 8: 147163.

Bruggen, A.C. van. (1981). The African element among the terrestrial molluscs of the island of Madagascar. Proceedings of the Koninklijke Nederlandse Akademie van Wetenschappen, C 84: 115-129.

Bruggen, A.C. van. (1982). Some reflections, mainly biogeographical, on the land operculates (Mollusca, Gastropoda Prosobranchia) of the Afro-tropical region. Netherlands Journal of Zoology 32: 284-299.

Bruggen, A.C. van. (1986). Aspects of the diversity of the land molluscs of the Afrotropical Region. Revue Zoologique Africaine 100: 29-45.

Bruggen, A.C. van. (1993). Studies on the terrestrial molluscs of Malawi, an interim progress report with additions to the checklist. Archiv fuir Molluskenkunde 122: 99-111.

Bruggen, A.C. van. (1995). Biodiversity of the Mollusca: time for a new approach. In A. C. van Bruggen, S. Wells and C.M. Kemperman (eds), Biodiversity and Conservation of the Mollusca: 1-19. Backhuys, Oegstgeest-Leiden, Netherlands.

Bruggen, A.C. van and Meredith, H. M. (1984). A 
preliminary analysis of the land-snails of Malawi. In A. Solem and A.C. van Bruggen (eds), World-wide Snails: Biogeographical Studies on Non-marine Mollusca: 156-171. Backhuys, Leiden, Netherlands.

Burgess, N.D. and Clarke, G.P. (eds), (2000). Coastal Forests of Eastern Africa. IUCN, Gland, Switzerland.

Bursey, M.L. and Herbert, D.G. (2004). Four new narrowrange endemic species of Gulella from Eastern Cape, South Africa (Mollusca: Pulmonata: Streptaxidae). African Invertebrates 45: 249-262.

Connolly, M. (1939). A monographic survey of South African non-marine Mollusca. Annals of the South African Museum 33: 1-660.

Emberton, K.C. (1994). Thirty new species of Madagascan land snails (Mollusca: Gastropoda). Proceedings of the Academy of Natural Sciences, Philadelphia 145: 147-189.

Emberton, K.C. (1995a). Land-snail community morphologies of the highest-diversity sites of Madagascar, North America, and New Zealand, with recommended alternatives to height-diameter plots. Malacologia 36: 43-66.

Emberton, K.C. (1995b). On the endangered biodiversity of Madagascan land snails. In A.C. van Bruggen, S. Wells and C.M. Kemperman, (eds), Biodiversity and Conservation of the Mollusca: 69-89. Oegstgeest-Leiden, The Netherlands, Backhuys Publishers.

Emberton, K.C., Pearce, T.A., Kasigwa, P., Tattersfield, P. and Habibu, Z. (1997). High diversity and regional endemism in land-snails of eastern Tanzania. Biodiversity \& Conservation 6: 1123-1136.

Emberton, K.C., Pearce, T.A., and Randalana, R. (1999). Molluscan diversity in the unconserved Vohimena and the conserved Anosy mountain chains, southeast Madagascar. Biological Conservation 89: 183-188.

Germain, L. (1923). Voyage de M. Guy Babault dans l'Afrique Orientale Anglaise. Résultats Scientifiques. Mollusques Terrestres et Fluviatiles. Paris, France.

Germain, L. (1934). Contributions à la faune malacologique de l'Afrique équatoriale. LXVIII. Mollusques terrestres nouveaux des regions montagneuses de l'Afrique orientale (Mission de l'Omo 1932-33). Bulletin de la Musée de l'Histoire Naturelle de Paris 6: 262-270.

Germain, L. (1935). Contributions à l'étude de la Faune du Mozambique: Voyage de M.P. Lesne (1928-1929). 17e note - Mollusques Terrestres et Fluviatiles. Memórias e Estudos do Museu Zoológico da Universidade de Coimbra 80.

Herbert, D.G. (2002). Gulella salpinx sp. n. a new critically endangered holoendemic species from the limestone deposits of the Marble Delta, KwaZulu-Natal, South Africa (Mollusca: Gastropoda: Streptaxidae). African Invertebrates 43: 125-138.

Herbert, D.G., and Kilburn, D. (2004). Field Guide to the Land Snails and Slugs of Eastern South Africa. Natal Museum, Pietermaritzburg, South Africa.

Herbert, D.G., Seddon, M.B. and Tattersfield, P. (in prep). KwaZulu Natal data.

Lange, C.N. (2003). Environmental factors influencing land snail diversity patterns in Arabuko-Sokoke forest, Kenya. African Journal of Ecology 41: 352-355.

Lange, C.N. Mwinzi, M. (2003). Snail diversity, abundance and distribution in Arabuko Sokoke forest, Kenya. African Journal of Ecology, 41 (1): 61-67.

Martens, C. von. (1897). Beschalte Weichthiere Deutch-OstAfrikas. In Mobius, Deutch Ost-Afrika 4, Abt 1. 308 pp, 7 pl. Berlin.

Myers, N., Mittermeier, R.A., Mittermeier, C.G., de Fonseca, G.A.B. and Kent, J. (2000). Biodiversity hotspots for conservation priorities. Nature 403: 853858.

Mittermeier, R.A., Mittermeier, C.G., Brooks, T.M., Pilgrim, J.D., Konstant, W.R., da Fonseca, G.A.B. and Kormos, C. (2003). Wilderness and biodiversity conservation. Proceedings of the National Academy of Sciences USA 100 (18): 10309-10313.

Pearce, T.A. (2003). Gastropoda, terrestrial snails. In Goodman, S.M. and Benstead, J.P. (eds), The Natural History of Madagascar: 529-574. University of Chicago Press: Chicago.

Pilsbry, H.A. (1919). A review of the land mollusks of the Belgian Congo based on the collections of the American Museum Congo Expedition 1909-1915. Bulletin of the American Museum of Natural History 40: 1-370.

Seddon, M.B., Tattersfield, P., Rowson, B., Lange, C.N., Warui, C. and Ngereza, C. (in prep). Illustrated Checklists to the Land Molluscs of Kenya \& Tanzania.

Solem, A. (1984). A world model of land snail diversity and abundance. In A. Solem and. A.C. van Bruggen (eds), World-wide snails: Biogeographical Studies on Nonmarine Mollusca: 6-22. Backhuys, Leiden, Netherlands.

Solem, A., Climo, F.M. and Roscoe, D.J. (1981). Sympatric species diversity of New Zealand and snails. New Zealand Journal of Zoology 8: 453-485.

Tattersfield, P. (1996). Local patterns of land-snail diversity in a Kenyan rain forest. Malacologia 38, 161180.

Tattersfield, P. (1996a). Biodiversity and conservation of Land Molluscs (Snails and Slugs) of Forests of Tanzania. Contribution No. 1 - Studies In Forests Of The Coastal Zone and near Amani, East Usambaras. Unpublished progress report to Tanzania Commission for Science and Technology, Dar es Salaam, Tanzania.

Tattersfield, P. (1997). Biodiversity and Conservation of Land Molluscs (Snails and Slugs) of Forests of Tanzania. Contribution No. 2 - Studies in Eastern Arc Forests. Unpublished progress report to Tanzania Commission for Science and Technology, Dar es Salaam, Tanzania.

Tattersfield, P. (1998). Patterns of diversity and endemism in East African land snails, and the implications for conservation. Journal of Conchology Special Publication 2: 77-86.

Tattersfield, P., Seddon, M.B., Meena, C., Kayumbo, N., and Kasigwa, P. (1998). Ecology and Conservation of the land-snails of the Eastern Arc Mountains. Journal of East African Natural History 87: 119-138.

Tattersfield, P., Warui, C.M., Seddon, M.B. and Kiringe, J.W. (2001a). Land-snail faunas of afromontane forests of Mount Kenya, Kenya: ecology, diversity and distribution patterns. Journal of Biogeography 28: 843861. 
Tattersfield, P., Paul, C.R.C., and Allen, J.A. (2001b). Columella in sub-Saharan Africa: a range expansion of over 4000 kilometres? Journal of Conchology 37: 281285.

Tattersfield, P., Seddon, M.B. and Lange, C.N. (2001c). Land-snail faunas in indigenous rainforest and commercial forestry plantations in Kakamega Forest, western Kenya. Biodiversity and Conservation 10: 18091829.

Tattersfield, P., Seddon, M.B., Ngereza, C., and Rowson, $B$. (in review). Elevational variation in diversity and composition of land-snail faunas in a Tanzanian forest. Submitted to African Journal of Ecology.

Verdcourt, B. (1972). The zoogeography of the nonmarine Mollusca of East Africa. Journal of Conchology 27: 291-348.

Verdcourt, B. (1983). A list of the non-marine Mollusca of East Africa (Kenya, Uganda, Tanzania, excluding Lake Malawi). Achatina 11: 200-239.

Verdcourt, B. (1984). Discontinuities in the distribution of some East African land snails. In A. Solem and A.C. van Bruggen (eds), World-wide Snails: Biogeographical Studies on Non-marine Mollusca: 134-155. Backhuys, Leiden, Netherlands.
Solem, A. and Bruggen, A.C. van. (eds). (1984). Worldwide Snails: Biogeographical Studies on Non-marine Mollusca. Backhuys, Leiden, Netherlands.

Warui, C.M., Tattersfield, P. and Seddon, M.B. (2001). Annotated checklist of the non-marine molluscs of Mount Kenya, Kenya. Journal of Conchology 37: 291300.

White, F. (1983). The Vegetation of Africa: a Descriptive Memoir to Accompany the Unesco/AETFAT/UNSO Vegetation Map of Africa. Unesco, Paris, France.

Whittaker, R.H. (1970). Communities and Ecosystems. Macmillan, London, UK.

Winter, A. J. de and Gittenberger, E. (1998). The land snail fauna of a square kilometer patch of rainforest in South-western Cameroon: high species richness, low abundance and seasonal fluctuations. Malacologia 40: $231-250$. 